\title{
FERTILIZATION IN VITRO OF MOUSE AND HAMSTER EGGS AFTER THE REMOVAL OF FOLLICULAR CELLS
}

\author{
H. MIYAMOTO and M. C. CHANG \\ Worcester Foundation for Experimental Biology, Inc., \\ Shrewsbury, Massachusetts 01545, U.S.A.
}

(Received 25th January 1972, accepted 17th March 1972)

\begin{abstract}
Summary. The removal of follicular cells decreased the proportion of mouse eggs penetrated by epididymal spermatozoa, but did not affect the proportion of hamster eggs penetrated, whether the spermatozoa were taken from the epididymis or from the uterus.
\end{abstract}

In the rabbit, the cumulus oophorus is said to be dispersed by hyaluronidase released from the sperm acrosome (Austin, 1961) and corona radiata cells are removed by a tubal factor (Swyer, 1947). It has been postulated that the presence of cumulus oophorus may decrease the incidence of polyspermy and increase the chance of fertilization, and that the corona radiata cells may play a rôle in the orientation of spermatozoa approaching the eggs (Austin, 1961).

After the dissolution of the cumulus oophorus by treatment with hyaluronidase and removal of the corona radiata by manual shaking, the denuded rabbit eggs can be fertilized in vitro (Bedford \& Chang, 1962). Recently, it was reported that removal of the cumulus oophorus and the corona radiata from rabbit eggs does not lower the proportion of eggs fertilized in vitro (Chang, Hanada \& Hunt, 1971; Fraser, Dandekar \& Vaidya, 1971). By contrast, Cross \& Brinster (1970) reported that the removal of the follicular cells from the mouse eggs reduced the fertilization rate inseminated with spermatozoa recovered from the uterus. Iwamatsu \& Chang (1970), however, reported that the percentage of eggs penetrated by spermatozoa preincubated with bovine follicular fluid was lower in mouse eggs with follicular cells than in those without follicular cells.

This experiment was designed to determine if the follicular cells surrounding the eggs have a particular rôle to play in the fertilization in vitro of mouse and hamster eggs.

Mature female CD-1 mice were subjected to the procedure of superovulation and their eggs were recovered according to the procedures reported elsewhere (Edwards \& Gates, 1959; Miyamoto \& Chang, 1972). One group of eggs in cumulus clot was placed in a watch glass containing $0.5 \mathrm{ml}$ of $0.003 \%$ hyaluronidase in a medium containing bovine serum albumin, sodium pyruvate (Toyoda, Yokoyama \& Hosi, 1971; Miyamoto \& Chang, 1972) plus 21.58 mm-sodium lactate; the other group was placed in another watch glass containing no hyaluronidase. After the dissolution of the cumulus oophorus and the corona radiata, 
the hyaluronidase-treated eggs were washed five times while the eggs in cumulus clot were washed twice in order to remove oviducal fluid. A sperm suspension was prepared by mincing cauda epididymidis of a mature male CD-1 mouse in a watch-glass containing $1 \mathrm{ml}$ medium. About $0 \cdot 1 \mathrm{ml}$ of sperm suspension was added to $0.1 \mathrm{ml}$ medium containing eggs under paraffin oil in a watch glass. After the further addition of about 0.2 to $0.3 \mathrm{ml}$ medium, the suspension was thoroughly mixed, and incubated at $37^{\circ} \mathrm{C}$ in an atmosphere of $5 \% \mathrm{CO}_{2}$ in air for 5 to $7 \mathrm{hr}$.

Mature female golden hamsters were also subjected to a procedure of superovulation (Yanagimachi \& Chang, 1964) and were killed 15 to $17 \mathrm{hr}$ after the injection of HCG for the recovery of eggs. The medium used for hamster eggs consisted of an equal volume of Tyrode's solution and heated hamster blood serum (at $56^{\circ} \mathrm{C}$ for 50 to $60 \mathrm{~min}$ ). The hamster eggs were similarly treated with hyaluronidase and washed as in the case of the mouse eggs. Hamster sperm suspension was prepared by placing spermatozoa obtained either from the cauda epididymidis or from the uterus of a hamster mated 3 to $4 \mathrm{hr}$ previously in $1.5 \mathrm{ml}$ Tyrode's solution. The procedure for in-vitro fertilization was the same as for mouse eggs. After incubation for 5 to $7 \mathrm{hr}$, the eggs were taken out, mounted on a slide and examined. They were then fixed with neutral formalin and stained for the assessment of fertilization (Miyamoto \& Chang, 1972).

From the results presented in Table 1, it can be seen that, after the removal of cumulus oophorus and the corona radiata cells, the denuded mouse eggs can be penetrated in vitro by epididymal spermatozoa and the hamster eggs can also be penetrated in vitro either by epididymal spermatozoa or by uterine spermatozoa. However, the proportion of penetrated eggs (89 versus $68 \%$ ) and that of eggs undergoing fertilization ( 85 versus $63 \%$ ) were significantly higher $(P<0.01)$ in the mouse eggs with follicular cells than in the denuded mouse eggs. This confirms the results reported by Cross \& Brinster (1970) who found a relatively higher proportion of fertilized eggs amongst those with follicular cells than amongst the denuded eggs (90 versus $46 \%$ ). Whether the relatively low proportion of penetrated eggs amongst the denuded mouse eggs is due to the lack of energy sources supplied by the follicular cells (Biggers, Whittingham \& Donahue, 1967; Donahue \& Stern, 1968), to lack of progesterone produced by follicular cells for the induction of the acrosome reaction (Edwards, Steptoe \& Purdy, 1970) or to the rapid loss of fertilizability in the mouse eggs after the removal of follicular cells as in the rabbit eggs (Chang \& Bedford, 1962), is difficult to say at present. Since a relatively high proportion of mouse eggs with follicular cells was fertilized in chemically defined media (Cross \& Brinster, 1970 ; and present study) while a low proportion of mouse eggs with follicular cells was fertilized by preincubated spermatozoa in the presence of bovine follicular fluid (Iwamatsu \& Chang, 1970), it may be assumed that the capacitation of spermatozoa and the fertilization of mouse eggs in vitro are more dependent on the medium used than on the presence or absence of follicular cells. There was no significant difference in the proportions of hamster eggs fertilized, whether they were denuded or not ( 87 to $88 \%$ versus 84 to $91 \%$ ) and whether epididymal or uterine spermatozoa were used ( 87 to $91 \%$ versus 84 to $88 \%$ ). This confirms the statement by Yanagimachi (1969) that cumulus oophorus 


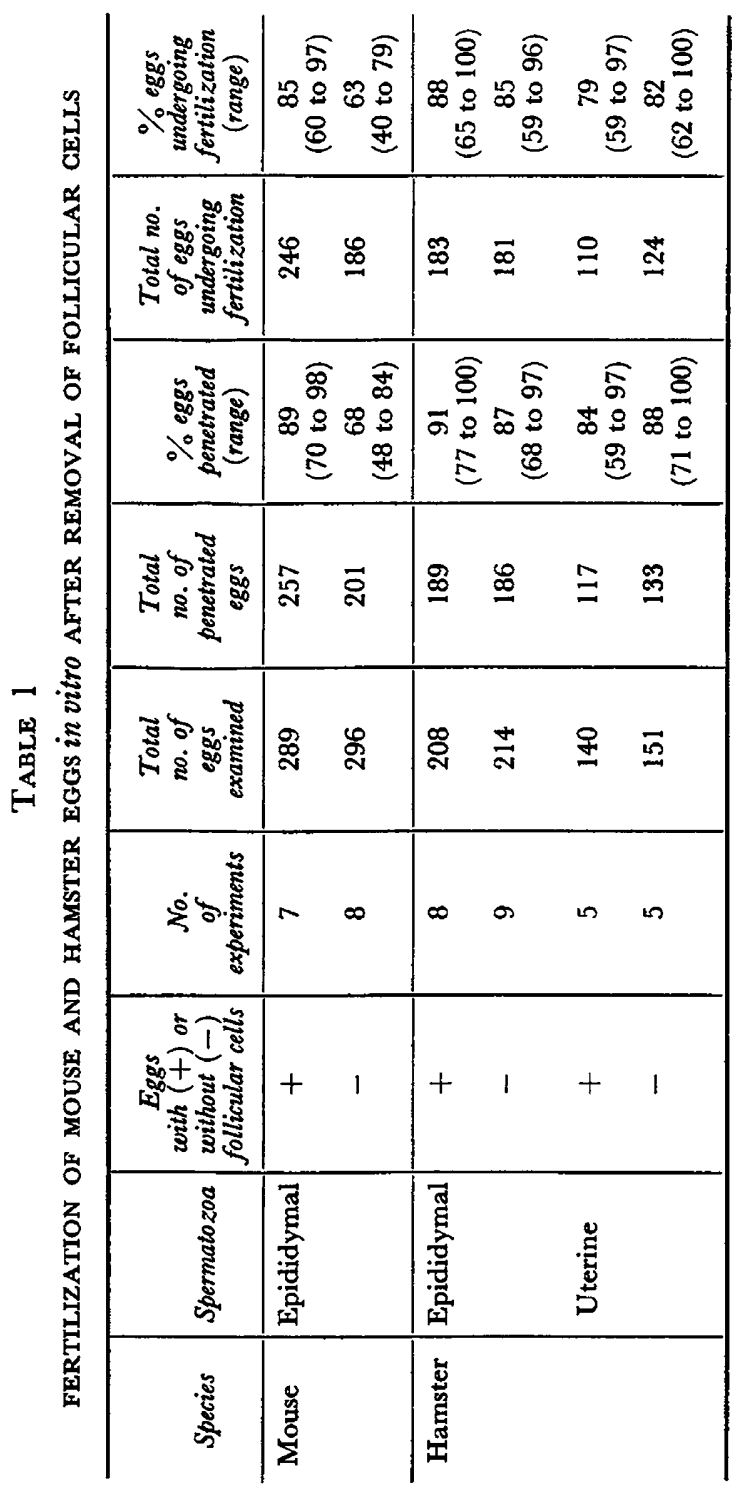


and corona radiata cells have no power to induce the capacitation of hamster epididymal spermatozoa. Since the absence of follicular cells does not hinder the penetration of spermatozoa in vitro in the rabbit (Chang et al., 1971; Fraser et al., 1971) and in the hamster (the present study), while the presence of follicular cells appears to facilitate the penetration of mouse eggs (Cross \& Brinster, 1970; present study), the possibility of a species difference concerning the rôle of follicular cells for fertilization cannot be excluded.

This work was supported by grants from the U.S. Public Health Service (GM 14370) and the Ford Foundation.

\section{REFERENCES}

Austriv, C. R. (1961) The mammalian egg. Blackwell Scientific Publications, Oxford.

Bedrord, J. M. \& Chang, M. C. (1962) Fertilization of rabbit ova in vitro. Nature, Lond. 193, 898.

Biggers, J. D., Whittingham, D. G. \& Donahue, R. P. (1967) The pattern of energy metabolism in the mouse oocyte and zygote. Proc. natn. Acad. Sci. U.S.A. 58, 560.

Chang, M. C. \& BEDFord, J. M. (1962) Fertilizability of rabbit ova after removal of the corona radiata. Fert. Steril. 13, 421.

Chang, M. G., Hanada, A. \& Hunt, D. M. (1971) Fertilization of denuded rabbit eggs in vitro by sperm recovered from the uterus or vagina. Nature, Lond. 232, 343.

CRoss, P. C. \& Brinster, R. L. (1970) In vitro development of mouse oocytes. Biol. Reprod. 3, 298.

Donahue, R. P. \& STERN, S. (1968) Follicular cell support of oocyte maturation: production of pyruvate in vitro. F. Reprod. Fert. 17, 395.

EDWARDS, R. G. \& GATES, A. H. (1959) Timing of the stages of maturation division, ovulation, fertilization and the first cleavage of adult mice treated with gonadotrophin. F. Endocr. 18, 292.

Edwards, S., Steptoe, P. \& Purdy, J. (1970) Fertilization and cleavage in vitro of preovulator human oocytes. Nature, Lond. 227, 1307.

Fraser, L. R., Dandekar, P. V. \& Vatwya, R. A. (1971) In vitro fertilization of tubal rabbit ova partially or totally denuded of follicular cells. Biol. Reprod. 4, 229.

Iwamatsu, T. \& Ghang, M. C. (1970) Further investigation of capacitation of sperm and fertilization of mouse eggs in vitro. F. exp. Zool. 175, 271.

Mryamoto, H. \& Chang, M. C. (1972) The importance of serum albumin and metabolic intermediates for capacitation of spermatozoa and fertilization of mouse eggs in vitro. 7. Reprod. Fert. (In press).

Swyer, G. (1947) A tubal factor concerned in the denudation of rabbit ova. Nature, Lond. 159, 873.

Toyoda, Y., Yokoyama, M. \& Hosr, T. (1971) Studies on the fertilization of mouse eggs in vitro. I. In vitro fertilization of eggs by fresh epididymal sperm. Fap. J. Anim. Reprod. 16, 147.

YANagimachI, R. (1969) In vitro capacitation of hamster spermatozoa by follicular fluid. J. Reprod. Fert. $18,275$.

Yanagimachi, R. \& Chang, M. G. (1964) In vitro fertilization of golden hamster ova. J. exp. Zool. 156, 361. 